\title{
Adsorption of Carbon Dioxide, Methane, and Nitrogen on Zn(dcpa) Metal-Organic Framework
}

\author{
Rui P. P. L. Ribeiro *(D), Isabel A. A. C. Esteves (D) and José P. B. Mota * \\ LAQV-REQUIMTE, Department of Chemistry, NOVA School of Science and Technology, \\ NOVA University of Lisbon, 2829-516 Caparica, Portugal; i.esteves@fct.unl.pt \\ * Correspondence: rpp.ribeiro@fct.unl.pt (R.P.P.L.R.); pmota@fct.unl.pt (J.P.B.M.)
}

Citation: Ribeiro, R.P.P.L.; Esteves, I.A.A.C.; Mota, J.P.B. Adsorption of Carbon Dioxide, Methane, and Nitrogen on Zn(dcpa) Metal-Organic Framework. Energies 2021, 14, 5598. https://doi.org/10.3390/en14185598

Academic Editor: Francesco Frusteri

Received: 11 August 2021

Accepted: 3 September 2021

Published: 7 September 2021

Publisher's Note: MDPI stays neutral with regard to jurisdictional claims in published maps and institutional affiliations.

Copyright: (c) 2021 by the authors. Licensee MDPI, Basel, Switzerland. This article is an open access article distributed under the terms and conditions of the Creative Commons Attribution (CC BY) license (https:// creativecommons.org/licenses/by/ $4.0 /)$.

\begin{abstract}
Adsorption-based processes using metal-organic frameworks (MOFs) are a promising option for carbon dioxide $\left(\mathrm{CO}_{2}\right)$ capture from flue gases and biogas upgrading to biomethane. Here, the adsorption of $\mathrm{CO}_{2}$, methane $\left(\mathrm{CH}_{4}\right)$, and nitrogen $\left(\mathrm{N}_{2}\right)$ on $\mathrm{Zn}$ (dcpa) MOF (dcpa (2,6-dichlorophenylacetate)) is reported. The characterization of the MOF by powder X-ray diffraction (PXRD), thermogravimetric analysis (TGA), and $\mathrm{N}_{2}$ physisorption at $77 \mathrm{~K}$ shows that it is stable up to $650 \mathrm{~K}$, and confirms previous observations suggesting framework flexibility upon exposure to guest molecules. The adsorption equilibrium isotherms of the pure components $\left(\mathrm{CO}_{2}, \mathrm{CH}_{4}\right.$, and $\left.\mathrm{N}_{2}\right)$, measured at $273-323 \mathrm{~K}$, and up to $35 \mathrm{bar}$, are Langmuirian, except for that of $\mathrm{CO}_{2}$ at $273 \mathrm{~K}$, which exhibits a stepwise shape with hysteresis. The latter is accurately interpreted in terms of the osmotic thermodynamic theory, with further refinement by assuming that the free energy difference between the two metastable structures of $\mathrm{Zn}(\mathrm{dcpa})$ is a normally distributed variable due to the existence of different crystal sizes and defects in a real sample. The ideal selectivities of the equimolar mixtures of $\mathrm{CO}_{2} / \mathrm{N}_{2}$ and $\mathrm{CO}_{2} / \mathrm{CH}_{4}$ at 1 bar and $303 \mathrm{~K}$ are 12.8 and 2.9, respectively, which are large enough for $\mathrm{Zn}(\mathrm{dcpa})$ to be usable in pressure swing adsorption.
\end{abstract}

Keywords: Zn(dcpa); MOF; framework flexibility; adsorption; gas storage; biogas; carbon capture

\section{Introduction}

Metal-organic frameworks (MOFs) are being touted as the next generation materials for several adsorptive separation and purification processes [1,2]. MOFs are porous crystalline materials consisting of metal centers connected by organic moieties [3]. An unlimited amount of MOF structures can be envisioned and perhaps synthesized; furthermore, the materials can be tailored for specific applications through pore size tuning and functionalization [4]. These features place MOFs as a very diverse class of materials with potential applications in nearly all fields of chemical engineering [5-12].

Among the available portfolio of MOFs, there are several structures that present structural flexibility, which can be triggered by exposure to specific guest species, changes in temperature or mechanical pressure, or interactions with light or electric fields [13,14]. Framework flexibility generally manifest itself through breathing or gate-opening effects [13]. A comprehensive review regarding MOF flexibility was published by Schneemann et al. [14], in which it is stated that, so far, less than a hundred MOFs have shown important breathing effects. The authors classified the type of flexibility into "breathing", "swelling", "linker rotation", and "subnetwork displacement". The most well-known cases of MOF flexibility are the breathing behavior of MIL-53 [15-17] and the gate-opening of ZIF-8 [18,19].

The MIL-53 family of MOFs consists of trivalent metal (e.g., Al [20], Cr [17], Fe [21], and Sc [22]) terephthalates, which can switch between large-pore (lp) and narrow-pore (np) forms [15-17], with unit cell volume variation of up to $40 \%$ [23]. The conformational change can be triggered by different stimuli, for example temperature changes [22,24], application of mechanical pressure $[25,26]$, and adsorption of guest molecules (such as 
$\mathrm{H}_{2} \mathrm{O}, \mathrm{CO}_{2}$, and other gases) $[20,22,26,27]$. Interestingly, the synthesis route and solvents employed critically impact the breathing properties of MIL-53 [28], and several authors have observed the absence of the breathing effect in the commercial MIL-53(Al) synthesized by BASF (Basolite@A100) when exposed to $\mathrm{CO}_{2}$ [29-31].

Another type of MOF flexibility is related to linker rotation [32], of which the most well-known example occurs in ZIF-8, which presents a gate-opening effect $[18,19]$. The linker rotation triggers a window opening that allows for the adsorption of larger molecules than expected [18].

Recently, MOFs with step-shaped isotherms typical of flexible MOFs have been considered as potential adsorbents for $\mathrm{CO}_{2}$ capture by temperature swing adsorption (TSA), as they permit decreasing the energy consumption of the process when compared with traditional zeolite 13X systems [33].

$\mathrm{Zn}(\mathrm{dcpa})$ is a poorly studied microporous MOF that reportedly exhibits dynamic behavior and stepwise adsorption. $\mathrm{Zn}(\mathrm{dcpa})$ is based on paddle-wheel $\mathrm{Zn}_{2}$ units and unsymmetrical pyridyl dicarboxylate, which give rise to a three-dimensional intersecting pore network with a pore opening of $6.3 \times 12.2 \AA^{2}$ [34]. The $\mathrm{Zn}(\mathrm{dcpa})$ framework structure is shown in Figure 1. Liu et al. [34] observed the dynamic behavior of Zn(dcpa) upon exposure to $\mathrm{N}_{2}$ and $\mathrm{CO}_{2}$ at $77 \mathrm{~K}$ and $195 \mathrm{~K}$, respectively. However, they did not observe the MOF's flexible behavior when adsorbing $\mathrm{CO}_{2}$ at 273 and $293 \mathrm{~K}$ and $\mathrm{N}_{2}$ at $293 \mathrm{~K}$, up to 1 bar.

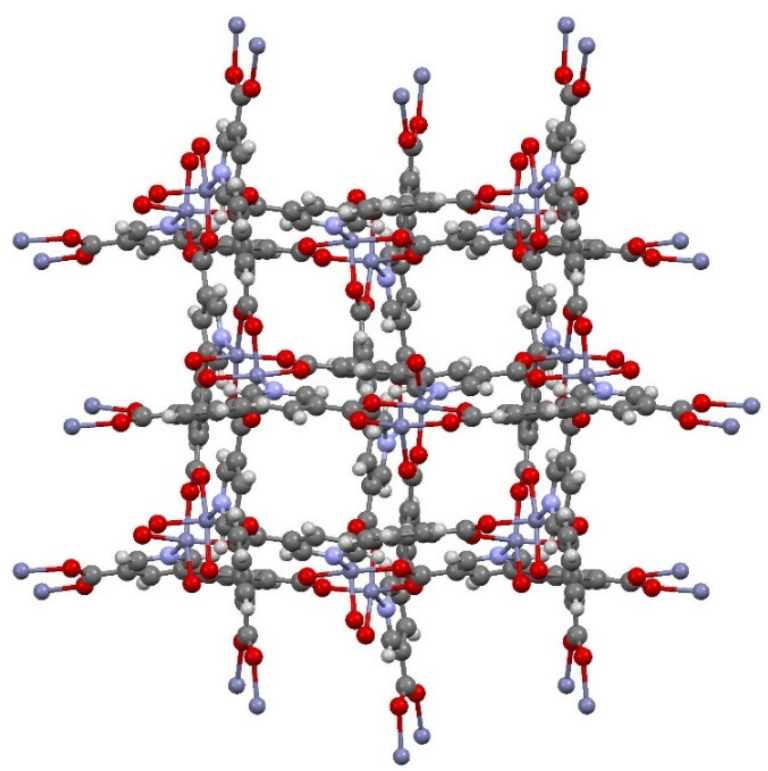

Figure 1. View of the $\mathrm{Zn}(\mathrm{dcpa})$ framework along the c-axis (Zn: blue, O: red, C: grey, and H: white). Data generated from the CIF file reported by Liu et al. [34].

In this work, the potential of $\mathrm{Zn}(\mathrm{dcpa})$ for application in the separation/purification of gaseous streams containing $\mathrm{CO}_{2}, \mathrm{CH}_{4}$, and $\mathrm{N}_{2}$, namely post-combustion $\mathrm{CO}_{2}$ capture and biogas upgrading, is evaluated. For this purpose, the single-component adsorption equilibria of $\mathrm{CO}_{2}, \mathrm{CH}_{4}$, and $\mathrm{N}_{2}$ have been measured at $273-323 \mathrm{~K}$ up to $35 \mathrm{bar}$, and the isosteric heat of adsorption and ideal $\mathrm{CO}_{2} / \mathrm{CH}_{4}$ and $\mathrm{CO}_{2} / \mathrm{N}_{2}$ equilibrium selectivities evaluated. Furthermore, the MOF has been characterized regarding its textural properties and thermal stability. The uncommon stepwise adsorption and hysteretic desorption behavior for $\mathrm{CO}_{2}$ at $273 \mathrm{~K}$ has been interpreted in terms of the osmotic thermodynamic theory. The data reported here add important knowledge about the adsorption properties of $\mathrm{Zn}(\mathrm{dcpa})$, as prior studies about this MOF are limited to a few publications [34,35]. 


\section{Materials and Methods}

\subsection{Materials}

The $\mathrm{Zn}$ (dcpa) MOF sample employed was synthesized at the Materials Center at Technical University Dresden (Germany). After its synthesis, the sample was washed with DMF and, subsequently, activated at $453 \mathrm{~K}$ under vacuum for $24 \mathrm{~h}$. The gases employed in the measurements were provided by Air Liquide and Praxair (Portugal) with purities of 99.998\% $\left(\mathrm{CO}_{2}\right), 99.95 \%\left(\mathrm{CH}_{4}\right), 99.99 \%\left(\mathrm{~N}_{2}\right)$, and $99.999 \%(\mathrm{He})$.

\subsection{Zn(dcpa) Characterization}

The sample was characterized using powder X-ray diffraction (PXRD), thermogravimetric analysis (TGA), $\mathrm{N}_{2}$ physisorption at $77 \mathrm{~K}$, and helium porosimetry. The $\mathrm{N}_{2}$ adsorption isotherm at $77 \mathrm{~K}$ and PXRD were determined by the supplier upon request. TGA analysis was performed using a LABSYS Evo TGA-DTA/DSC from SETARAM Instrumentation, under an argon flow at a heating rate of $3 \mathrm{~K} / \mathrm{min}$ (up to $1130 \mathrm{~K}$ ). Helium picnometry was performed at $323 \mathrm{~K}$, in a gravimetric apparatus (described in the next section), to determine the skeletal density of the $\operatorname{MOF}\left(\rho_{\mathrm{s}}\right)$.

\subsection{Single-Component Adsorption Equilibrium}

Single-component adsorption equilibrium isotherms of $\mathrm{CO}_{2}, \mathrm{CH}_{4}$, and $\mathrm{N}_{2}$ at $273 \mathrm{~K}$, $303 \mathrm{~K}$, and $323 \mathrm{~K}$, between 0 and 35 bar, were determined using the standard static gravimetric method $[31,36,37]$. The measurements were performed in a high-pressure magneticsuspension balance ISOSORP 2000 (Rubotherm GmbH, Germany) using approximately $600 \mathrm{mg}$ of $\mathrm{Zn}$ (dcpa) powder. Both the adsorption and desorption data were recorded to evaluate the hysteretic effects. The sample was received from the supplier already activated and stored in an argon atmosphere, which is why the pre-treatment performed before measuring the adsorption equilibrium isotherms was limited to overnight vacuum. The experimental setup and procedure are detailed elsewhere [31,37].

The excess amount adsorbed, $q_{\mathrm{exc}}$, is determined as follows

$$
q_{\mathrm{exc}}=\frac{w-m_{\mathrm{s}}-m_{\mathrm{h}}+V_{\mathrm{h}} \rho_{\mathrm{g}}}{m_{\mathrm{s}}}+v_{\mathrm{s}} \rho_{\mathrm{g}}
$$

where $w$ is the apparent mass weighted; $m_{\mathrm{s}}$ is the mass of MOF; $V_{\mathrm{h}}$ and $m_{\mathrm{h}}$ correspond to the volume and mass of the measuring cell, respectively, which contribute to the buoyancy effects; $\rho_{\mathrm{g}}$ is the density of the bulk gas at the experimental conditions; and $v_{\mathrm{s}}$ is the specific volume of the solid matrix of the $\operatorname{MOF}\left(v_{\mathrm{s}}=1 / \rho_{\mathrm{s}}\right.$, where $\rho_{\mathrm{s}}$ is the skeletal density of the adsorbent). $v_{\mathrm{s}}$ was determined by helium pycnometry performed at $323 \mathrm{~K}$ in the gravimetric apparatus. This was determined assuming that He penetrates the MOF pore volume without being adsorbed.

The absolute amount adsorbed, $q$, can be determined from the excess amount adsorbed, using the following

$$
q=q_{\operatorname{exc}}\left(\frac{\rho_{1}}{\rho_{1}-\rho_{\mathrm{g}}}\right)
$$

assuming that the adsorbed phase density corresponds to the density of the liquid at its boiling point at $1 \mathrm{~atm}\left(\rho_{1}\right)$ [38].

\section{Results and Discussion}

\subsection{Zn(dcpa) Characterization}

The PXRD patterns obtained are displayed in Figure 2, showing that the position of the reflexes changed during activation. This effect was also observed by Liu et al. [34], who associated it with framework shrinkage upon removal of the guest molecules. The authors also observed the reversibility of this phenomenon when readsorbing the solvent. 


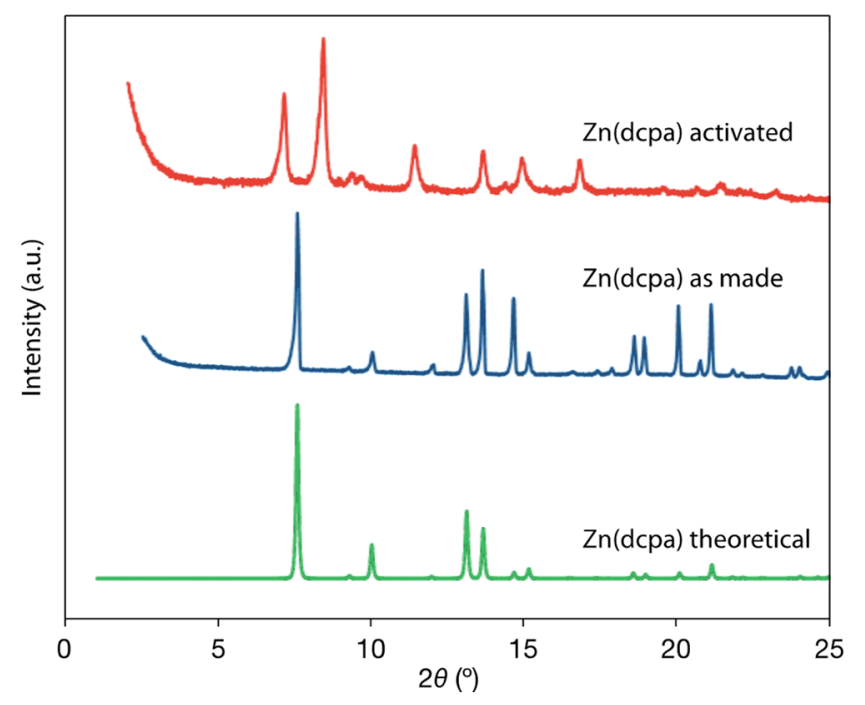

Figure 2. PXRD diffraction pattern for activated, as made, and theoretical $\mathrm{Zn}$ (dcpa) samples.

The thermal stability of the sample was also characterized by TGA; the recorded sample mass as a function of the heating temperature is shown in Figure 3 . The results show an initial mass decrease $(\sim 10 \%)$ from room temperature up to around $400 \mathrm{~K}$, due to the removal of pre-adsorbed impurities and humidity, due to MOF exposure to the indoor atmosphere just prior to the analysis. MOF was stable up to $650 \mathrm{~K}$, after which a steep decrease in the mass was observed, reaching a mass decrease of $50 \%$, similar to the behavior observed by Liu et al. [34]. Above $750 \mathrm{~K}$, the $\mathrm{Zn}(\mathrm{dcpa})$ mass decreased more smoothly until reaching the remaining experimental amount of ca. $25 \%$ at $1130 \mathrm{~K}$.

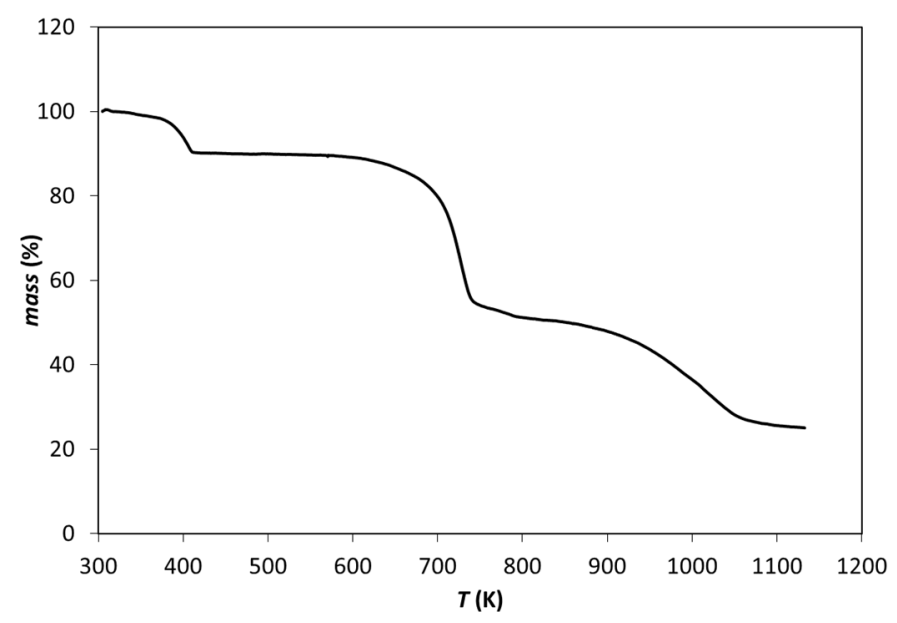

Figure 3. TGA results for $\mathrm{Zn}(\mathrm{dcpa})$ as a function of temperature (heating rate of $3 \mathrm{~K} / \mathrm{min}$ ).

The $\mathrm{Zn}(\mathrm{dcpa})$ porosity was evaluated by $\mathrm{N}_{2}$ adsorption at $77 \mathrm{~K}$. The obtained isotherm is plotted in Figure 4, showing an initial step followed by a smoother increase until $p / p_{0}=0.06$; then, another steep increase is observed before reaching a nearly constant plateau with only a small increase between $p / p_{0}=0.2\left(274 \mathrm{~cm}^{3} / \mathrm{g}\right)$ and $p / p_{0}=0.97$ $\left(303 \mathrm{~cm}^{3} / \mathrm{g}\right)$. Note that $p$ and $p_{0}$ are the equilibrium and saturation pressures of the adsorbate at $77 \mathrm{~K}$, respectively. The same behavior was observed by Liu et al. [34] who attributed the first step of the isotherm to the $\mathrm{Zn}(\mathrm{dcpa})$ structure with shrunken pores, and the second step to an expanded structure. In our work, the expanded structure had a specific pore volume of $0.47 \mathrm{~cm}^{3} / \mathrm{g}$, determined at a relative pressure of $p / p_{0}=0.97$, assuming the pores were filled with condensed liquid $\mathrm{N}_{2}$ at its normal boiling point. The desorption branch showed hysteresis at $p / p_{0}<0.2$, which is also in accordance with a previous report, although in our case, the hysteresis loop seemed to close at lower 
pressures-which corresponds to a return to the shrunken pore conformation-as opposed to the observation of Liu et al. [34].
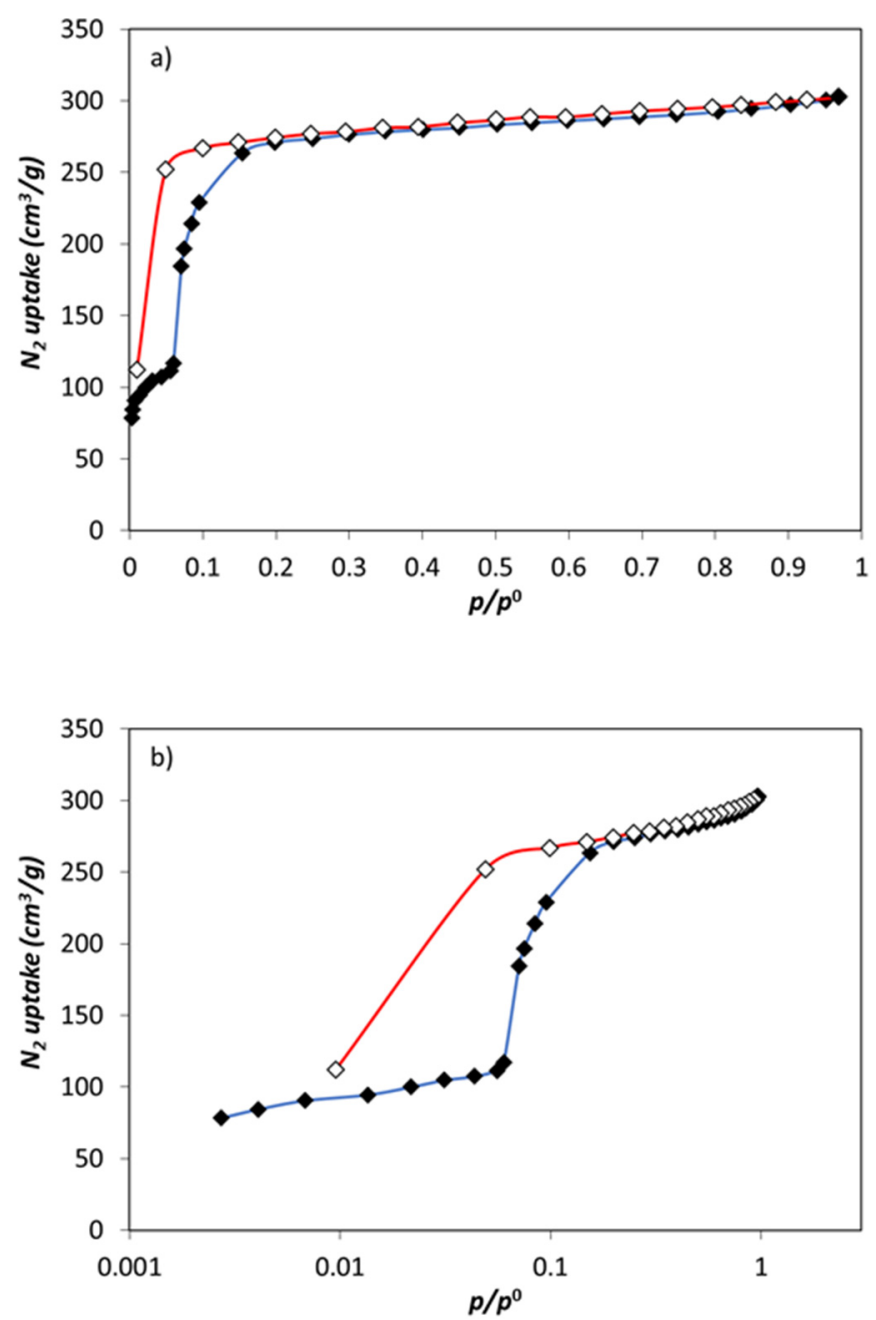

Figure 4. $\mathrm{N}_{2}$ adsorption equilibrium isotherm at $77 \mathrm{~K}$ on $\mathrm{Zn}(\mathrm{dcpa})$ in linear (a) and $\log (\mathbf{b})$ scales. Filled and empty symbols represent the adsorption and desorption data, respectively.

\subsection{Single-Component Adsorption Equilibrium}

Prior to the adsorption of $\mathrm{CO}_{2}, \mathrm{CH}_{4}$, and $\mathrm{N}_{2}$, the skeletal density of $\mathrm{Zn}(\mathrm{dcpa})$ was determined by helium picnometry at $323 \mathrm{~K}$, obtaining a $\rho_{\mathrm{s}}=1.74 \mathrm{~g} / \mathrm{cm}^{3}\left(v_{\mathrm{s}}=1 / \rho_{\mathrm{s}}=\right.$ $\left.0.575 \mathrm{~cm}^{3} / \mathrm{g}\right)$. For a purely crystalline porous material with a regular lattice, $v_{\mu}+v_{\mathrm{s}}$ is equal to the specific volume of the unit cell of the lattice. The particle density determined, $\rho_{\mathrm{p}}=1 /\left(v_{s}+v_{\mu}\right)=0.957 \mathrm{~g} / \mathrm{cm}^{3}$, is in excellent agreement with the value obtained from the crystallographic data $\left(\rho_{\mathrm{p}}=0.961 \mathrm{~g} / \mathrm{cm}^{3}\right)$ by Liu et al. [34].

The adsorption equilibria of $\mathrm{CO}_{2}, \mathrm{CH}_{4}$, and $\mathrm{N}_{2}$ on the $\mathrm{Zn}$ (dcpa) MOF were measured at 273,303 , and $323 \mathrm{~K}$ over the pressure range of 0 to 35 bar. The $\mathrm{CO}_{2}, \mathrm{CH}_{4}$, and $\mathrm{N}_{2}$ absolute adsorption equilibrium isotherms obtained are reported in Figures 5-7, respectively. The $\mathrm{CO}_{2}$ adsorption isotherms were quite steep in the Henry region, showing a high adsorption capacity at a low pressure, an important feature for use in post-combustion $\mathrm{CO}_{2}$ capture applications. On the other hand, the $\mathrm{N}_{2}$ adsorption isotherms were much more linear and had lower adsorption capacity; the $\mathrm{CH}_{4}$ adsorption isotherms were intermediate between those of $\mathrm{CO}_{2}$ and $\mathrm{N}_{2}$. 


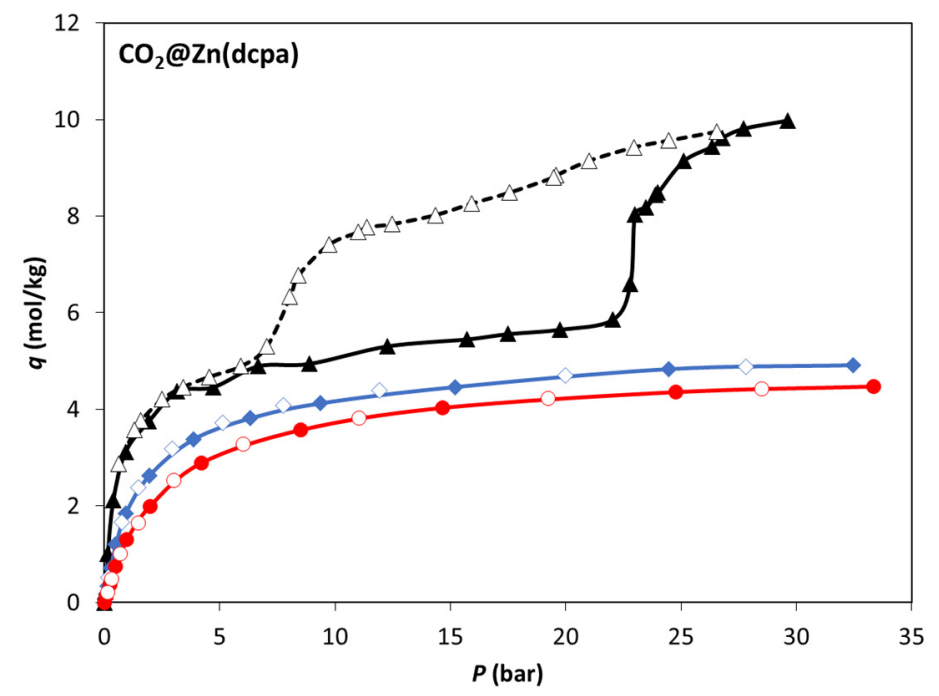

Figure 5. Absolute adsorption equilibrium isotherms of $\mathrm{CO}_{2}$ on $\mathrm{Zn}(\mathrm{dcpa})$ at $273 \mathrm{~K}(\boldsymbol{\Delta}), 303 \mathrm{~K}(\boldsymbol{\vee})$, and $323 \mathrm{~K}(\bullet)$. Filled and empty symbols represent adsorption and desorption experimental data, respectively.

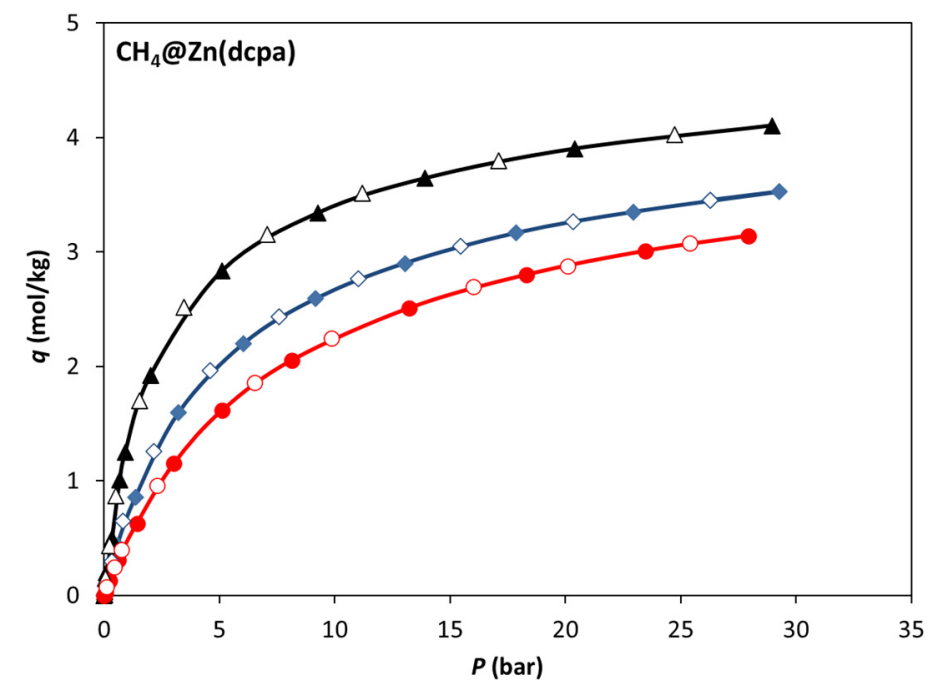

Figure 6. Absolute adsorption equilibrium isotherms of $\mathrm{CH}_{4}$ on $\mathrm{Zn}(\mathrm{dcpa})$ at $273 \mathrm{~K}(\boldsymbol{\Lambda}), 303 \mathrm{~K}(\boldsymbol{\vee})$, and $323 \mathrm{~K}(\bullet)$. Filled and empty symbols represent adsorption and desorption experimental data, respectively.

An interesting feature of the $\mathrm{CO}_{2}$ adsorption equilibrium isotherms can be observed in Figure 5. At $273 \mathrm{~K}$, the adsorption branch of the isotherm follows a typical Langmuirtype shape up to approximately $22 \mathrm{bar}$, where a step in the isotherm is observed. This behaviour is similar to that observed by Liu et al. [34] for $\mathrm{CO}_{2}$ adsorption at $195 \mathrm{~K}$, which the authors related to the transition between a shrunken-pore phase and an expanded-pore one. The desorption branch then follows a different path than the adsorption one, showing a hysteresis loop that closes at 7 bar. The reproducibility of this behaviour was checked by repeating the measurements. The stepwise $\mathrm{CO}_{2}$ adsorption observed is an interesting feature of $\mathrm{Zn}(\mathrm{dcpa})$ that can be explored for gas separation or storage applications. It can enhance the working capacity of the solid material upon mild pressure or temperature swings [33]. Despite the observation of the MOF flexibility for $\mathrm{CO}_{2}$ adsorption at $273 \mathrm{~K}$, the same behaviour was not observed for any of the other temperatures nor for the adsorbate species tested $\left(\mathrm{CH}_{4}\right.$ and $\left.\mathrm{N}_{2}\right)$. 


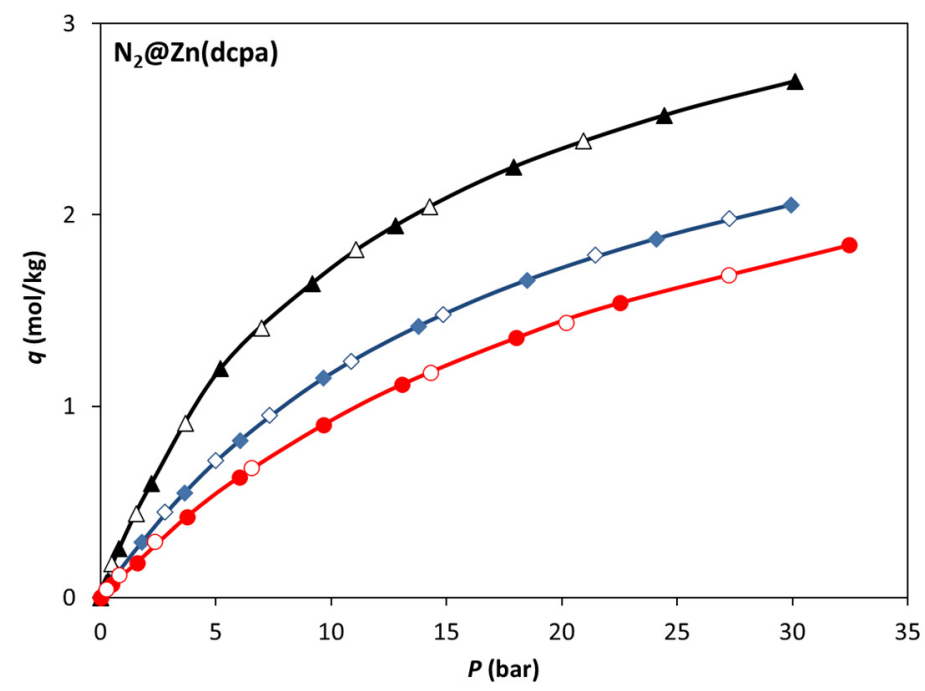

Figure 7. Absolute adsorption equilibrium isotherms of $\mathrm{N}_{2}$ on $\mathrm{Zn}(\mathrm{dcpa})$ at $273 \mathrm{~K}(\boldsymbol{\Delta}), 303 \mathrm{~K}(\boldsymbol{\bullet})$, and $323 \mathrm{~K}(\bullet)$. Filled and empty symbols represent adsorption and desorption experimental data, respectively.

\subsection{Osmotic Thermodynamic Theory}

Some materials present clear transitions between different metastable framework structures. $\mathrm{Zn}(\mathrm{dcpa})$ is an example of such materials. In these cases, an "osmotic subensemble" [15,39-42] can be employed to describe the equilibrium between host structures when exposed to gaseous adsorbates. Alternatively, Ghysels et al. [42] proposed another free energy model able to describe the thermodynamics of breathing phenomena in flexible materials. In this work, we interpreted our data using the former approach.

The osmotic potential [43] of the solid-adsorbate system for the $i$ th structure of $\mathrm{Zn}(\mathrm{dcpa})$, either shrunken-pore (SP) or expanded-pore (EP), is

$$
\begin{gathered}
\Omega_{\text {os }}^{(i)}(P, T)=F_{\text {host }}^{(i)}(T)+P v_{\mathrm{p}}^{(i)}-\int_{0}^{P} q^{(i)}(P, T) v_{\mathrm{g}}(P, T) d P \\
\quad=F_{\text {host }}^{(i)}(T)+P v_{\mathrm{P}}^{(i)}-R T \int_{0}^{P} q^{(i)}(P, T) Z(P, T) d \ln P
\end{gathered}
$$

where $F_{\text {host }}^{(i)}(T)$ corresponds to the empty structure's free energy at temperature $T$ and $v_{\mathrm{p}}^{(i)}$ to its apparent specific volume (i.e., to the sum of its skeletal, $v_{\mathrm{s}}$, and porous, $v_{\mu}^{(i)}$, volumes); $q^{(i)}(P, T)$ corresponds to the adsorption isotherm considering a rigid framework in its $i$ th structural form; and $v_{\mathrm{g}}=1 / n_{\mathrm{g}}$ and $P$ are the molar volume and compressibility factor of the adsorptive. The difference in the osmotic potential between both of the structures considered (EP and SP), $\Delta \Omega_{\mathrm{os}}(P, T)=\Omega_{\mathrm{OS}}^{(\mathrm{EP})}(P, T)-\Omega_{\mathrm{oS}}^{(\mathrm{SP})}(P, T)$, is thus

$$
\Delta \Omega_{\mathrm{os}}(P, T)=\Delta F_{\text {host }}(T)+P \Delta v_{\mathrm{p}}-R T \int_{0}^{P} \Delta q(P, T) Z(P, T) d \ln P
$$

where $\Delta \phi \equiv \phi^{(\mathrm{EP})}-\phi^{(\mathrm{SP})}$ is the difference in the value of property $\phi$ between the EP and SP structures at temperature $T$. If $\Delta \Omega_{\mathrm{os}}>0$, the SP structure will be more stable than EP; if $\Delta \Omega_{\mathrm{OS}}<0$, the reverse will be true. For $\mathrm{Zn}(\mathrm{dcpa}), v_{\mu}^{(\mathrm{EP})}=0.47 \mathrm{~cm}^{3} / \mathrm{g}$ and $v_{\mu}^{(\mathrm{SP})}=0.14 \mathrm{~cm}^{3} / \mathrm{g}$; hence $\Delta v_{\mathrm{p}}=\left(v_{\mathrm{S}}+v_{\mu}\right)^{(\mathrm{EP})}-\left(v_{\mathrm{S}}+v_{\mu}\right)^{(\mathrm{SP})} \approx v_{\mu}^{(\mathrm{EP})}-v_{\mu}^{(\mathrm{SP})}=0.33 \mathrm{~cm}^{3} / \mathrm{g}$. Assuming ideal gas behavior $(Z \approx 1)$, the previous equation can be simplified to

$$
\Delta \Omega_{\mathrm{os}}(P, T) \approx \Delta F_{\text {host }}(T)+P \Delta v_{\mathrm{p}}-R T \int_{0}^{P} \Delta q(P, T) d \ln P .
$$

If $\Delta F_{\text {host }}$ and $\Delta q(P)$ are known at a given temperature $T$, putting $\Delta \Omega_{\mathrm{OS}}=0$ in Equation (4) (or Equation (5)) and solving it for $P$ gives the pressure at which the phase transition occurs at $T$. However, in real scenarios, the MOF crystals have defects and the 
sample has a distribution of crystal sizes, both contributing to smoothing the structural transitions between the two metastable framework structures. Here, we extend the osmotic thermodynamic theory to account for this diffuse effect. It is assumed that for a real sample, $\Delta F_{\text {host }}$ is normally (Gaussian) distributed around the corresponding value for a perfect crystal with a probability density function

$$
f\left(\Delta F_{\text {host }}\right)=\frac{1}{\sigma_{\Delta F} \sqrt{2 \pi}} \exp \left(-\frac{1}{2} \frac{\left(\Delta F_{\text {host }}-\Delta F_{\mu}\right)^{2}}{\sigma_{\Delta F}^{2}}\right),
$$

where $\Delta F_{\mu}$ is the mean or expectation of the distribution (i.e., the value of $\Delta F_{\text {host }}$ for a perfect crystal) and $\sigma_{\Delta F}$ is its standard deviation. Given that in the case under study, the structural transition is triggered by exposure to a specific guest species, the previous hypothesis is almost equivalent to considering that the adsorptive pressure, $P$, that triggers the structural transition at a fixed temperature is also a normally distribute variable and, therefore, that its cumulative distribution function, $\Phi(P)$, at a fixed temperature is

$$
\Phi(P) \equiv \int f(P) d P=\frac{1}{2}\left[1+\operatorname{erf}\left(\frac{P-P_{\mu}}{\sigma_{P} \sqrt{2}}\right)\right]
$$

where $P_{\mu}$ is the mean or expectation of the distribution (i.e., the transition pressure for a perfect crystal) and $\sigma_{P}$ is its standard deviation. Note that $\Phi(x)=\operatorname{prob}(P \leq x)$, where the right-hand side represents the probability that $P$ takes on a value less than or equal to $x$. Therefore, the macroscopically observed adsorption branch of the isotherm for a real sample is given by

$$
\begin{aligned}
& q_{\mathrm{ads}}(P)=\left[1-\Phi_{\mathrm{ads}}(P)\right] q^{(\mathrm{SP})}(P)+\Phi_{\mathrm{ads}}(P) q^{(\mathrm{EP})}(P) \\
& q_{\mathrm{des}}(P)=\left[1-\Phi_{\mathrm{des}}(P)\right] q^{(\mathrm{SP})}(P)+\Phi_{\mathrm{des}}(P) q^{(\mathrm{EP})}(P)
\end{aligned} \quad(\text { fixed } T)
$$

where $q^{(i)}(P, T)$ is the adsorption isotherm considering a rigid framework constrained to its $i$ th form.

This model was fitted to our experimental data, assuming the adsorption isotherms for the metastable forms of the framework are Langmuirian, i.e.,

$$
q^{(i)}(P)=\frac{q_{\infty}^{(i)} b^{(i)} P}{1+b^{(i)} P}
$$

where $q_{\infty}^{(i)}$ and $b^{(i)}$ are the saturation capacity and equilibrium constant for the $i$ th form, respectively, in which case Equation (5) reduces to

$$
\Delta \Omega_{\mathrm{os}}(P, T)=\Delta F_{\text {host }}(T)+P \Delta v_{\mathrm{p}}-R T\left[q_{\infty}^{(\mathrm{EP})} \ln \left(1+b^{(\mathrm{EP})} P\right)-q_{\infty}^{(\mathrm{SP})} \ln \left(1+b^{(\mathrm{SP})} P\right)\right]
$$

Table 1 lists the parameter values resulting from the model fitting to the experimental data, saturation capacity and Langmuir equilibrium constant $\left(q_{\infty}^{(i)}\right.$ and $\left.b^{(i)}\right)$ for $\mathrm{CO}_{2}$ adsorption at $273 \mathrm{~K}$ in the SP and EP metastable structures of $\mathrm{Zn}(\mathrm{dcpa})$, mean and standard deviation $\left(P_{\mu}\right.$ and $\left.\sigma_{\mu}\right)$ of the Gaussian distribution of adsorptive pressure that triggers the phase transition along the adsorption and desorption branches of the isotherm, and the corresponding free energy changes of the empty structure $\left(\Delta F_{\text {host }}\right)$. 
Table 1. Fitted parameters of the osmotic thermodynamic theory to the adsorption (Ads) and desorption (Des) branches of the experimental CO2 isotherm at $273 \mathrm{~K} . \Delta F_{\text {host }} \equiv F_{\text {host }}^{(\mathrm{EP})}-F_{\text {host }}^{(\mathrm{SP})}$.

\begin{tabular}{ccccccc}
\hline & $\begin{array}{c}\boldsymbol{q}_{\infty} \\
(\mathbf{m o l} / \mathbf{k g})\end{array}$ & $\begin{array}{c}\boldsymbol{b} \\
(\mathbf{a t m}\end{array}$ & & $\begin{array}{c}\boldsymbol{P}_{\boldsymbol{\mu}} \\
\mathbf{( a t m})\end{array}$ & $\begin{array}{c}\sigma_{\boldsymbol{P}} \\
(\mathbf{a t m})\end{array}$ & $\begin{array}{c}\Delta \boldsymbol{F}_{\text {host }} \\
\mathbf{( J / g )}\end{array}$ \\
\hline SP & 5.65 & 1.30 & Ads & 23.0 & 1.3 & -4.45 \\
$\mathrm{EP}$ & 12.2 & 0.143 & Des & 7.0 & 0.5 & -10.7 \\
\hline
\end{tabular}

Figure 8 compares the experimental adsorption data and the fitted osmotic thermodynamic model, and shows that excellent agreement with the experimental results has been reached using the proposed procedure, substantiated by the fact that the plotted adsorption and desorption curves accurately reproduce the experimental data.

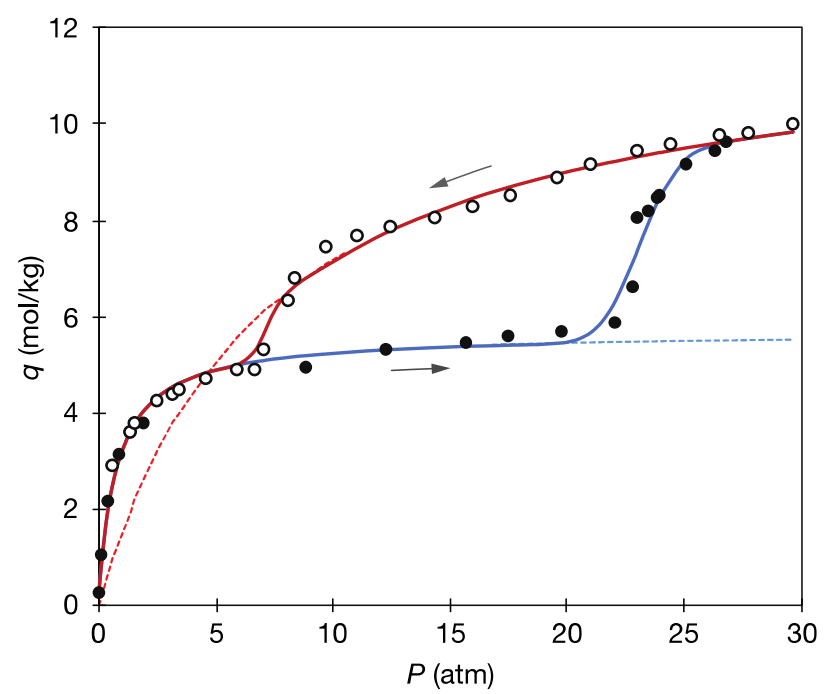

Figure 8. Fitting of the osmotic thermodynamic theory to the adsorption $(\bullet)$ and desorption $(\bigcirc)$ branches of the experimental $\mathrm{CO}_{2}$ isotherm at $273 \mathrm{~K}$. Dashed lines: fitted Langmuir adsorption isotherms if the framework were rigid and constrained to its EP (-- $)$ and SP (- - ) forms; solid lines: predicted adsorption (-) and desorption (- branches of the isotherm at $273 \mathrm{~K}$.

The first two numeric columns of Table 2 list the parameter values of the Langmuir adsorption isotherm model that best fit the $\mathrm{CH}_{4}$ and $\mathrm{N}_{2}$ experimental adsorption data at $273 \mathrm{~K}$ (Figure 9); these values apply when the framework is in its SP form. The last two columns of Table 2 list the corresponding values if the framework were hypothetically in $\mathrm{EP}$ form; given the absence of experimental data, the Langmuir parameters were estimated using the following scaling rules:

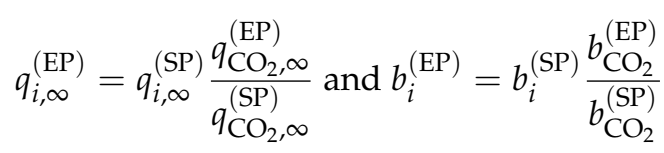

Although these rules are rather crude and their application cannot be considered quantitatively precise, they allow us to explain why the adsorption isotherms of $\mathrm{CH}_{4}$ and $\mathrm{N}_{2}$ do not point to a phase transition between the SP and EP structures (and no hysteresis) in the pressure range tested experimentally by us. The reason is that in the case of $\mathrm{CH}_{4}$ or $\mathrm{N}_{2}$ adsorption, the pressure must be increased considerably, well above the maximum experimental value tested by us, for the term $R T \int_{0}^{P} \Delta q(P, T) d \ln P$ to change the sign of $\Delta \Omega_{\mathrm{os}}$. A similar reasoning explains why the $\mathrm{CO}_{2}$ adsorption isotherms at $303 \mathrm{~K}$ and $323 \mathrm{~K}$ do not hint at a phase transition between the SP and EP structures. 
Table 2. Fitting of the Langmuir adsorption isotherm model to the $\mathrm{CH}_{4}$ and $\mathrm{N}_{2}$ experimental adsorption data at $273 \mathrm{~K}$. The parameters for the EP form are estimated as $q_{i, \infty}^{(\mathrm{EP})}=q_{i, \infty}^{(\mathrm{SP})} q_{\mathrm{CO}_{2}, \infty}^{(\mathrm{EP})} / q_{\mathrm{CO}_{2}, \infty}^{(\mathrm{SP})}$ and $b_{i}^{(\mathrm{EP})}=b_{i}^{(\mathrm{SP})} b_{\mathrm{CO}_{2}}^{(\mathrm{EP})} / b_{\mathrm{CO}_{2}}^{(\mathrm{SP})}$.

\begin{tabular}{ccccc}
\hline & $\begin{array}{c}\boldsymbol{q}_{\infty}^{(\mathrm{SP})} \\
(\mathbf{m o l} / \mathbf{k g})\end{array}$ & $\begin{array}{c}\boldsymbol{b}^{(\mathrm{SP})} \\
\left(\mathbf{a t m} \mathbf{- 1}^{-1}\right.\end{array}$ & $\begin{array}{c}\boldsymbol{q}_{\infty}^{(\mathrm{EP})} \\
(\mathbf{m o l} / \mathbf{k g})\end{array}$ & $\begin{array}{c}\boldsymbol{b}^{(\mathrm{EP})} \\
\left(\mathbf{a t m} \mathbf{- 1}^{-\mathbf{1}}\right)\end{array}$ \\
\hline $\mathrm{N}_{2}$ & 3.681 & 0.089 & 7.948 & 0.010 \\
$\mathrm{CH}_{4}$ & 4.328 & 0.411 & 9.346 & 0.045 \\
\hline
\end{tabular}

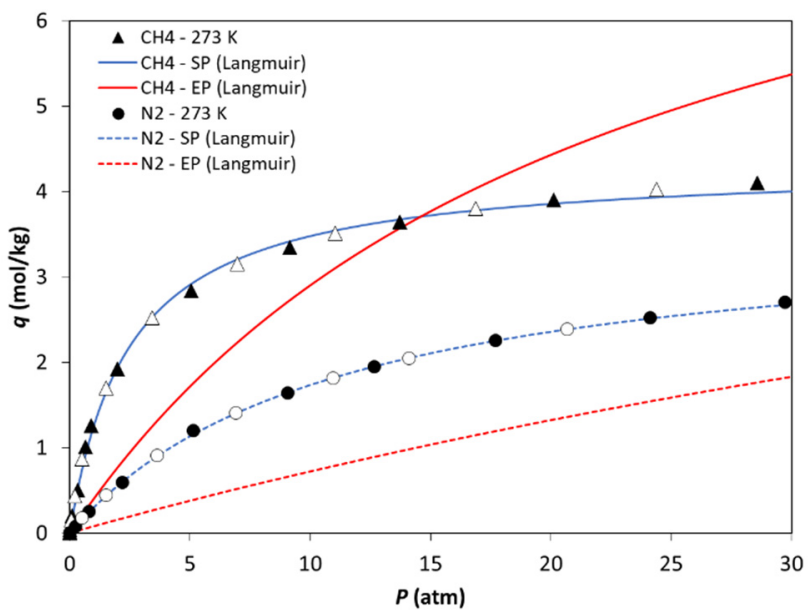

Figure 9. Fitting of the Langmuir isotherm model to the $\mathrm{CH}_{4}(\boldsymbol{\Delta})$ and $\mathrm{N}_{2}(\bullet)$ experimental adsorption equilibrium isotherms at $273 \mathrm{~K}$. Filled and empty symbols denote experimental adsorption and desorption data, respectively. Solid lines: fitted $\mathrm{CH}_{4}$ Langmuir isotherm for rigid framework constrained to its EP (red) and SP (blue) forms; dashed lines: fitted $\mathrm{N}_{2}$ Langmuir isotherm for rigid framework constrained to its EP (red) and SP (blue) forms.

\subsection{Potential of $\mathrm{Zn}(\mathrm{dcpa})$ for $\mathrm{CO}_{2} / \mathrm{N}_{2}$ and $\mathrm{CO}_{2} / \mathrm{CH}_{4}$ Separation}

To assess the potential use of $\mathrm{Zn}(\mathrm{dcpa})$ for the adsorptive separation of $\mathrm{CO}_{2} / \mathrm{N}_{2}$ and $\mathrm{CO}_{2} / \mathrm{CH}_{4}$, we first compared the single-component equilibrium isotherms and the obtained selectivities. Figure 10a compares the isotherms obtained at $303 \mathrm{~K}$ for the three gases. The ideal selectivity for an equimolar mixture, $\alpha_{\mathrm{A} / \mathrm{B}}=q_{\mathrm{A}} / q_{\mathrm{B}}$, was calculated using the single-component adsorption capacity ratio; the obtained results are reported in Figure $10 \mathrm{~b}, \mathrm{c}$ for the $\mathrm{CO}_{2} / \mathrm{N}_{2}$ and $\mathrm{CO}_{2} / \mathrm{CH}_{4}$ selectivities, respectively. Both the $\mathrm{CO}_{2} / \mathrm{N}_{2}$ and $\mathrm{CO}_{2} / \mathrm{CH}_{4}$ selectivities decreased with the increasing pressure, ranging from 12.8 (at 1 bar) to 6.7 (6 bar) for $\mathrm{CO}_{2} / \mathrm{N}_{2}$, and from 2.9 (at 1 bar) to 2.1 (6 bar) for $\mathrm{CO}_{2} / \mathrm{CH}_{4}$. The $\mathrm{CO}_{2} / \mathrm{N}_{2}$ selectivity was significantly higher than that of $\mathrm{CO}_{2} / \mathrm{CH}_{4}$, especially at a lower pressure. Although the reported equilibrium selectivity did not take into account the influence of adsorption kinetics or the impact of a real gas mixture, these results serve as a first evaluation of the good potential of $\mathrm{Zn}$ (dcpa) for $\mathrm{CO}_{2}$ separation from $\mathrm{CO}_{2} / \mathrm{N}_{2}$ and $\mathrm{CO}_{2} / \mathrm{CH}_{4}$ mixtures. Comparing the selectivity of $\mathrm{Zn}$ (dcpa) for $\mathrm{CO}_{2} / \mathrm{N}_{2}$ with those of the commercial MOFs MIL-53(Al) [31], ZIF-8, [44], and Fe-BTC [45] (Figure 10b,c), it is concluded that the former outperformed the others at a lower pressure. For example, at 1 bar, the order of selectivities was $12.8(\mathrm{Zn}(\mathrm{dcpa}))>10.5(\mathrm{Fe}-\mathrm{BTC})>9.6(\mathrm{MIL}-53(\mathrm{Al}))>5.9$ (ZIF-8). The same can be said about the $\mathrm{CO}_{2} / \mathrm{CH}_{4}$ selectivity trend: $2.9(\mathrm{Zn}(\mathrm{dcpa}))>2.7$ $(\mathrm{MIL}-53(\mathrm{Al}))>2.6(\mathrm{ZIF}-8)$, although in this case, ZIF-8 surpassed $\mathrm{Zn}(\mathrm{dcpa})$ at pressures above 2.4 bar. 

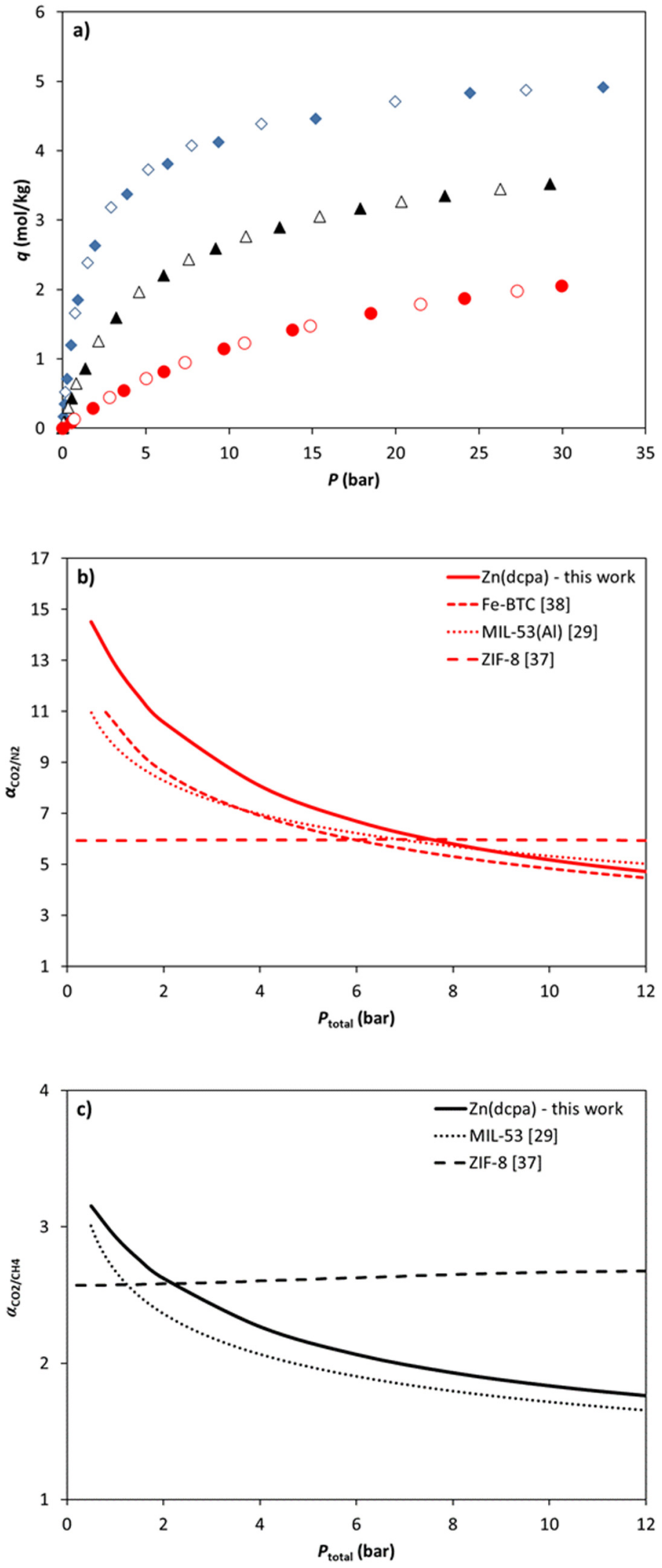

Figure 10. (a) Adsorption equilibrium isotherms of $\mathrm{CO}_{2}(\bullet), \mathrm{CH}_{4}(\mathbf{\Delta})$, and $\mathrm{N}_{2}(\bullet)$ on $\mathrm{Zn}(\mathrm{dcpa})$ at $303 \mathrm{~K}$. Filled and empty symbols represent adsorption and desorption data, respectively; (b) $\mathrm{CO}_{2} / \mathrm{N}_{2}$ and (c) $\mathrm{CO}_{2} / \mathrm{CH}_{4}$ equilibrium selectivity at $303 \mathrm{~K}$ as a function of pressure for $\mathrm{Zn}(\mathrm{dcpa})$ and commercial MOFs MIL-53(Al) [31], ZIF-8 [44], and Fe-BTC [45]. 
The isosteric heat of adsorption, $Q_{\text {st }}$, was determined from the experimental data via the Clausius-Clapeyron equation: $(\log P)_{q}=$ const $-Q_{\text {st }} / R T$ [46] Using this approach, the plot of $\log P$ versus $-1 / R T$, at constant loading, should give a straight line from which the slope of $Q_{\text {st }}$ can be obtained. The plots in Figure 11 of $Q_{\text {st }}$ for $\mathrm{CO}_{2}, \mathrm{CH}_{4}$, and $\mathrm{N}_{2}$ on $\mathrm{Zn}$ (dcpa) as a function of loading show that for $\mathrm{CH}_{4}$, their values were approximately constant within the loading range studied, while for $\mathrm{CO}_{2}$ and $\mathrm{N}_{2}$, a linear increase was observed. It should be noted that in the case of $\mathrm{CO}_{2}, Q_{\text {st }}$ was plotted for loadings lower than the MOF's conformational change observed at $273 \mathrm{~K}$, i.e., less than $4 \mathrm{~mol} / \mathrm{kg}$. The isosteric heat of the adsorption was higher for $\mathrm{CO}_{2}(23-28 \mathrm{~kJ} / \mathrm{mol})$, which is in accordance with the values reported in the literature [34], followed by that for $\mathrm{CH}_{4}(\sim 19.5 \mathrm{~kJ} / \mathrm{mol})$ and $\mathrm{N}_{2}(13-15 \mathrm{~kJ} / \mathrm{mol})$.

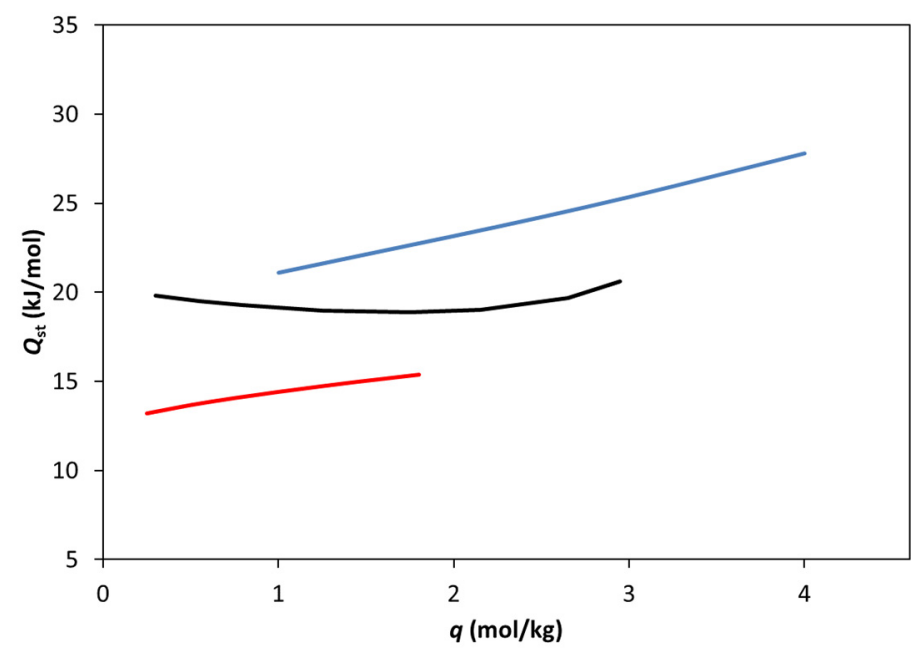

Figure 11. $\mathrm{CO}_{2}$ (blue), $\mathrm{CH}_{4}$ (black), and $\mathrm{N}_{2}$ (red) isosteric heats of adsorption, $Q_{\text {st }}$, as a function of loading, $q$.

\section{Conclusions}

$\mathrm{Zn}$ (dcpa) MOF was characterized through PXRD, thermogravimetric analysis, and $\mathrm{N}_{2}$ adsorption at $77 \mathrm{~K}$. In line with the XRD and $\mathrm{N}_{2}$ data reported by Liu et al. [34], our results indicate that the framework conformation changes (pore shrinkage/pore expansion) upon removal/loading of guest molecules. The TGA results demonstrate that the MOF is stable up to $650 \mathrm{~K}$.

The adsorption equilibrium isotherms of $\mathrm{CO}_{2}, \mathrm{CH}_{4}$, and $\mathrm{N}_{2}$ on $\mathrm{Zn}($ dcpa) at $273 \mathrm{~K}$, $303 \mathrm{~K}$, and $323 \mathrm{~K}$ are reported up to 35 bar. The obtained data highlight the interesting behavior of $\mathrm{CO}_{2}$ adsorption at $273 \mathrm{~K}$, which exhibits a stepped isotherm related to the transition between shrunken- and expanded-pore phases at around 22 bar. When observing the desorption branch of the isotherm, a hysteresis loop is present, closing at 7 bar. Although the same behavior is observed for $\mathrm{CO}_{2}$ adsorption at $195 \mathrm{~K}$ [34], this is the first report of this effect at $273 \mathrm{~K}$. None of the remaining $\mathrm{CO}_{2}(303 \mathrm{~K}$ and $323 \mathrm{~K}), \mathrm{CH}_{4}$, or $\mathrm{N}_{2}$ isotherms show the same behavior.

The $\mathrm{CO}_{2}$ adsorption equilibrium at $273 \mathrm{~K}$ is accurately interpreted using the osmotic thermodynamic theory, which is further refined by considering that the free energy difference between the two metastable structures of $\mathrm{Zn}(\mathrm{dcpa})$ is a normally distributed variable due to the distribution of crystal sizes and the defects in a real MOF sample.

Regarding the uptake amounts, $\mathrm{Zn}$ (dcpa) can adsorb higher amounts of $\mathrm{CO}_{2}$, followed by $\mathrm{CH}_{4}$ and $\mathrm{N}_{2}$. The $\mathrm{CO}_{2} / \mathrm{N}_{2}$ and $\mathrm{CO}_{2} / \mathrm{CH}_{4}$ ideal equilibrium selectivities of $\mathrm{Zn}(\mathrm{dcpa})$ at $303 \mathrm{~K}$ are evaluated for equimolar mixtures, resulting in 12.8 and 2.9, respectively, for a total pressure of 1 bar. 
The reported data are essential for the modelling of adsorption-based processes, namely pressure swing adsorption (PSA) and temperature swing adsorption (TSA), for the separation of mixtures containing the studied gases, e.g., biogas upgrading and $\mathrm{CO}_{2}$ capture from flue gases.

Author Contributions: Conceptualization, R.P.P.L.R. and J.P.B.M.; formal analysis, R.P.P.L.R. and J.P.B.M.; investigation, R.P.P.L.R. and I.A.A.C.E.; writing-original draft preparation, R.P.P.L.R.; writing - review and editing, R.P.P.L.R., I.A.A.C.E. and J.P.B.M.; visualization, R.P.P.L.R. and J.P.B.M. All authors have read and agreed to the published version of the manuscript.

Funding: This research was funded by the Associate Laboratory for Green Chemistry (AQV), which is financed by national funds from FCT /MCTES (UIDB/50006/2020 and UIDP/50006/2020). Rui Ribeiro and Isabel Esteves acknowledge financial support from FCT/MCTES through the Norma Transitória DL 57/2016 Program Contract and project IF/01016/2014, respectively. The authors also acknowledge support from the ERANet LAC initiative through project ELAC2014/BEE0367.

Conflicts of Interest: The authors declare no conflict of interest. The funders had no role in the design of the study; in the collection, analyses, or interpretation of data; in the writing of the manuscript; or in the decision to publish the results.

\section{References}

1. Herm, Z.R.; Swisher, J.A.; Smit, B.; Krishna, R.; Long, J.R. Metal-organic frameworks as adsorbents for hydrogen purification and precombustion carbon dioxide capture. J. Am. Chem. Soc. 2011, 133, 5664-5667. [CrossRef] [PubMed]

2. Grande, C.A.; Blom, R.; Andreassen, K.A.; Stensrød, R.E. Experimental results of pressure swing adsorption (PSA) for precombustion $\mathrm{CO}_{2}$ capture with metal organic frameworks. Energy Procedia 2017, 114, 2265-2270. [CrossRef]

3. Rowsell, J.L.C.; Yaghi, O.M. Metal-organic frameworks: A new class of porous materials. Micropor. Mesopor. Mat. 2004, 73, 3-14. [CrossRef]

4. Ferey, G. Hybrid porous solids: Past, present, future. Chem. Soc. Rev. 2008, 37, 191-214. [CrossRef] [PubMed]

5. Millward, A.R.; Yaghi, O.M. Metal-organic frameworks with exceptionally high capacity for storage of carbon dioxide at room temperature. J. Am. Chem. Soc. 2005, 127, 17998-17999. [CrossRef]

6. Furukawa, H.; Cordova, K.E.; O'Keeffe, M.; Yaghi, O.M. The chemistry and applications of metal-organic frameworks. Science 2013, 341. [CrossRef]

7. Czaja, A.U.; Trukhan, N.; Muller, U. Industrial applications of metal-organic frameworks. Chem. Soc. Rev. 2009, 38, 1284-1293. [CrossRef] [PubMed]

8. Meek, S.T.; Greathouse, J.A.; Allendorf, M.D. Metal-organic frameworks: A rapidly growing class of versatile nanoporous materials. Adv. Mater. 2011, 23, 249-267. [CrossRef]

9. Mueller, U.; Schubert, M.; Teich, F.; Puetter, H.; Schierle-Arndt, K.; Pastre, J. Metal-organic frameworks-Pospective industrial applications. J. Mater. Chem. 2006, 16, 626-636. [CrossRef]

10. Ribeiro, R.P.P.L.; Antunes, C.L.; Garate, A.U.; Portela, A.F.; Plaza, M.G.; Mota, J.P.B.; Esteves, I.A.A.C. Binderless shaped metal-organic framework particles: Impact on carbon dioxide adsorption. Microporous Mesoporous Mater. 2019, 275, 111-121. [CrossRef]

11. An, Y.; Tian, Y.; Li, Y.; Wei, C.; Tao, Y.; Liu, Y.; Xi, B.; Xiong, S.; Feng, J.; Qian, Y. Heteroatom-doped 3D porous carbon architectures for highly stable aqueous zinc metal batteries and non-aqueous lithium metal batteries. Chem. Eng. J. 2020, 400, 125843. [CrossRef]

12. An, Y.; Tian, Y.; Li, Y.; Xiong, S.; Zhao, G.; Feng, J.; Qian, Y. Green and tunable fabrication of graphene-like N-doped carbon on a 3D metal substrate as a binder-free anode for high-performance potassium-ion batteries. J. Mater. Chem. A 2019, 7, 21966-21975. [CrossRef]

13. Alhamami, M.; Doan, H.; Cheng, C.-H. A review on breathing behaviors of metal-organic-frameworks (MOFs) for gas adsorption. Materials 2014, 7, 3198-3250. [CrossRef]

14. Schneemann, A.; Bon, V.; Schwedler, I.; Senkovska, I.; Kaskel, S.; Fischer, R.A. Flexible metal-organic frameworks. Chem. Soc. Rev. 2014, 43, 6062-6096. [CrossRef]

15. Coudert, F.-X.; Mellot-Draznieks, C.; Fuchs, A.H.; Boutin, A. Double structural transition in hybrid material MIL-53 upon hydrocarbon adsorption: The termodynamics behind the scenes. J. Am. Chem. Soc. 2009, 131, 3442-3443. [CrossRef] [PubMed]

16. Mishra, P.; Edubilli, S.; Uppara, H.P.; Mandal, B.; Gumma, S. Effect of adsorbent history on adsorption characteristics of MIL-53 (Al) metal organic framework. Langmuir 2013, 29, 12162-12167. [CrossRef] [PubMed]

17. Serre, C.; Millange, F.; Thouvenot, C.; Noguès, M.; Marsolier, G.; Louër, D.; Férey, G. Very large breathing effect in the first nanoporous chromium (III)-based solids: MIL-53 or $\mathrm{Cr}$ III $(\mathrm{OH}) \cdot\left\{\mathrm{O}_{2} \mathrm{C}-\mathrm{C}_{6} \mathrm{H}_{4}-\mathrm{CO}_{2}\right\} \cdot\left\{\mathrm{HO}_{2} \mathrm{C}-\mathrm{C}_{6} \mathrm{H}_{4}-\mathrm{CO}_{2} \mathrm{H}\right\}_{x} \cdot \mathrm{H} 2 \mathrm{O}_{\mathrm{y}}$. J. Am. Chem. Soc. 2002, 124, 13519-13526. [CrossRef]

18. Fairen-Jimenez, D.; Galvelis, R.; Torrisi, A.; Gellan, A.D.; Wharmby, M.T.; Wright, P.A.; Mellot-Draznieks, C.; Duren, T. Flexibility and swing effect on the adsorption of energy-related gases on ZIF-8: Combined experimental and simulation study. Dalton Trans. 2012, 41, 10752-10762. [CrossRef] [PubMed] 
19. Fairen-Jimenez, D.; Moggach, S.A.; Wharmby, M.T.; Wright, P.A.; Parsons, S.; Düren, T. Opening the gate: Framework flexibility in ZIF-8 explored by experiments and simulations. J. Am. Chem. Soc. 2011, 133, 8900-8902. [CrossRef]

20. Loiseau, T.; Serre, C.; Huguenard, C.; Fink, G.; Taulelle, F.; Henry, M.; Bataille, T.; Ferey, G. A rationale for the large breathing of the porous aluminum terephthalate (MIL-53) upon hydration. Chem. Eur. J. 2004, 10, 1373-1382. [CrossRef] [PubMed]

21. Hamon, L.; Serre, C.; Devic, T.; Loiseau, T.; Millange, F.; Férey, G.; Weireld, G.D. Comparative study of hydrogen sulfide adsorption in the MIL-53 (Al, Cr, Fe), MIL-47 (V), MIL-100 (Cr), and MIL-101 (Cr) metal-rganic frameworks at room temperature. J. Am. Chem. Soc. 2009, 131, 8775-8777. [CrossRef]

22. Chen, L.; Mowat, J.P.S.; Fairen-Jimenez, D.; Morrison, C.A.; Thompson, S.P.; Wright, P.A.; Düren, T. Elucidating the breathing of the metal-organic framework MIL-53 (Sc) with ab initio molecular dynamics simulations and in situ X-ray powder diffraction experiments. J. Am. Chem. Soc. 2013, 135, 15763-15773. [CrossRef] [PubMed]

23. Boutin, A.; Coudert, F.X.; Springuel-Huet, M.A.; Neimark, A.V.; Férey, G.; Fuchs, A.H. The behavior of flexible MIL-53 (Al) upon $\mathrm{CH} 4$ and $\mathrm{CO}_{2}$ adsorption. J. Phys. Chem. C 2010, 114, 22237-22244. [CrossRef]

24. Liu, Y.; Her, J.-H.; Dailly, A.; Ramirez-Cuesta, A.J.; Neumann, D.A.; Brown, C.M. Reversible structural transition in MIL-53 with large temperature hysteresis. J. Am. Chem. Soc. 2008, 130, 11813-11818. [CrossRef] [PubMed]

25. Beurroies, I.; Boulhout, M.; Llewellyn, P.L.; Kuchta, B.; Férey, G.; Serre, C.; Denoyel, R. Using pressure to provoke the structural transition of metal-rganic frameworks. Angew. Chem. Int. Ed. 2010, 49, 7526-7529. [CrossRef]

26. Neimark, A.V.; Coudert, F.-X.; Triguero, C.; Boutin, A.; Fuchs, A.H.; Beurroies, I.; Denoyel, R. Structural transitions in MIL-53 (Cr): View from outside and inside. Langmuir 2011, 27, 4734-4741. [CrossRef]

27. Serre, C.; Bourrelly, S.; Vimont, A.; Ramsahye, N.A.; Maurin, G.; Llewellyn, P.L.; Daturi, M.; Filinchuk, Y.; Leynaud, O.; Barnes, P.; et al. An explanation for the very large breathing effect of a metal-organic framework during $\mathrm{CO}_{2}$ adsorption. Adv. Mater. 2007, 19, 2246-2251. [CrossRef]

28. Mounfield, W.P., III; Walton, K.S. Effect of synthesis solvent on the breathing behavior of MIL-53 (Al). J. Colloid Interface Sci. 2015, 447, 33-39. [CrossRef]

29. Heymans, N.; Vaesen, S.; De Weireld, G. A complete procedure for acidic gas separation by adsorption on MIL-53 (Al). Microporous Mesoporous Mater. 2012, 154, 93-99. [CrossRef]

30. Deniz, E.; Karadas, F.; Patel, H.A.; Aparicio, S.; Yavuz, C.T.; Atilhan, M. A combined computational and experimental study of high pressure and supercritical $\mathrm{CO}_{2}$ adsorption on Basolite MOFs. Microporous Mesoporous Mater. 2013, 175, 34-42. [CrossRef]

31. Camacho, B.C.R.; Ribeiro, R.P.P.L.; Esteves, I.A.A.C.; Mota, J.P.B. Adsorption equilibrium of carbon dioxide and nitrogen on the MIL-53 (Al) metal organic framework. Sep. Purif. Technol. 2015, 141, 150-159. [CrossRef]

32. Gonzalez-Nelson, A.; Coudert, F.X.; van der Veen, M.A. Rotational dynamics of linkers in metal-organic frameworks. Nanomaterials 2019, 9, 330. [CrossRef]

33. Hefti, M.; Joss, L.; Bjelobrk, Z.; Mazzotti, M. On the potential of phase-change adsorbents for $\mathrm{CO}_{2}$ capture by temperature swing adsorption. Faraday Discuss. 2016, 192, 153-179. [CrossRef]

34. Liu, B.; Li, Y.; Hou, L.; Yang, G.; Wang, Y.Y.; Shi, Q.-Z. Dynamic Zn-based metal-organic framework: Step wise adsorption, hysteretic desorption and selective carbon dioxide uptake. J. Mater. Chem. 2013, 1, 6535-6538. [CrossRef]

35. Ribeiro, R.P.P.L.; Barreto, J.; GrossoXavier, M.D.; Martins, D.; Esteves, I.A.A.C.; Branco, M.; Tirolien, T.; Mota, J.P.B.; Bonfait, G. Cryogenic neon adsorption on Co3 (ndc) 3 (dabco) metal-organic framework. Microporousand Mesoporous Mater. 2020, $298,110055$. [CrossRef]

36. Lyubchyk, A.; Esteves, I.A.A.C.; Cruz, F.J.A.L.; Mota, J.P.B. Experimental and theoretical studies of supercritical methane adsorption in the MIL-53 (Al) metal organic framework. J. Phys. Chem. 2011, 115, 20628-20638. [CrossRef]

37. Ribeiro, R.P.P.L.; Camacho, B.C.R.; Lyubchyk, A.; Esteves, I.A.A.C.; Cruz, F.J.A.L.; Mota, J.P.B. Experimental and computational study of ethane and ethylene adsorption in the MIL-53 (Al) metal organic framework. Microporousand Mesoporous Mater. 2016, 230, 154-165. [CrossRef]

38. Dreisbach, F.; Staudt, R.; Keller, J.U. High pressure adsorption data of methane, nitrogen, carbon dioxide and their binary and ternary mixtures on activated carbon. Adsorption 1999, 5, 215-227. [CrossRef]

39. Coudert, F.-X.; Jeffroy, M.; Fuchs, A.H.; Boutin, A.; Mellot-Draznieks, C. Thermodynamics of guest-induced structural transitions in hybrid organic-inorganic frameworks. J. Am. Chem. Soc. 2008, 130, 14294-14302. [CrossRef] [PubMed]

40. Mota, J.P.B.; Martins, D.; Lopes, D.; Catarino, I.; Bonfait, G. Structural transitions in the MIL-53 (Al) metal-organic framework upon cryogenic hydrogen adsorption. J. Phys. Chem. 2017, 121, 24252-24263. [CrossRef]

41. Hiraide, S.; Sakanaka, Y.; Kajiro, H.; Kawaguchi, S.; Miyahara, M.T.; Tanaka, H. High-through put gas separation by flexible metal-organic frameworks with fast gating and thermal management capabilities. Nat. Commun. 2020, 11, 3867. [CrossRef]

42. Ghysels, A.; Vanduyfhuys, L.; Vandichel, M.; Waroquier, M.; Van Speybroeck, V.; Smit, B. On the thermodynamics of framework breathing: A free energy model for gas adsorption in MIL-53. J. Phys. Chem. 2013, 117, 11540-11554. [CrossRef]

43. Jeffroy, M.; Fuchs, A.H.; Boutin, A. Structural changes in nanoporous solids due to fluid adsorption: Thermodynamic analysis and Monte Carlo simulations. Chem. Commun. 2008, 3275-3277. [CrossRef] [PubMed]

44. Ferreira, T.J.; Vera, A.T.; De Moura, B.A.; Esteves, L.M.; Tariq, M.; Esperança, J.M.S.S.; Esteves, I.A.A.C. Paramagnetic ionic liquid/metal organic framework composites for $\mathrm{CO}_{2} / \mathrm{CH} 4$ and $\mathrm{CO}_{2} / \mathrm{N} 2$ separations. Front. Chem. 2020, 8, 590191. [CrossRef] [PubMed] 
45. Nabais, A.R.; Ribeiro, R.P.P.L.; Mota, J.P.B.; Alves, V.D.; Esteves, I.A.A.C.; Neves, L.A. $\mathrm{CO}_{2} / \mathrm{N}_{2}$ gas separation using Fe (BTC)based mixed matrix membranes: A view on the adsorptive and filler properties of metal-organic frameworks. Sep. Purif. Technol. 2018, 202, 174-184. [CrossRef]

46. Poling, B.E.; Prausnitz, J.M.; O'Connell, J.P. The Properties of Gases and Liquids; McGraw-Hill: New York, NY, USA, 2001. 